\title{
Avaliação de Coliformes Totais e Escherichia coli em Diferentes Lotes de Água Mineral Comercializadas em um Município do Sudoeste Baiano
}

\author{
Gisele Norberto Mattos ${ }^{1}$; Luciana Gonçalves Lima²; Viviane Figueiredo Vieira ${ }^{3}$ \\ Stênio Fernando Pimentel Duarte
}

Resumo: A água, substância indispensável à saúde e a manutenção do corpo humano, bem como de todos os organismos vivos em nosso planeta, também se destaca como meio de disseminação de microrganismos patogênicos, como os coliformes totais e Escherichia coli, que são indicadores de contaminação fecal. Sendo assim, o presente estudo foi realizado com a finalidade de verificar a qualidade da água mineral vendida no comércio de um município baiano, utilizando o Aquatest Coli® (Laborclin), para realizar as análises de acordo com as orientações do fabricante. Os resultados demonstraram a inexistência de coliformes totais e de Escherichia coli em todas as amostras analisadas. Em estudos realizados em outros municípios, foram encontradas taxas de contaminação por coliformes totais e Escherichia coli, o que justifica a insegurança do consumidor.

Palavras-chave: Água mineral. Análise microbiológica. Coliformes totais. Escherichia coli.

\section{Total Coliforms and Escherichia coli Evaluation in Different Lots of Mineral Water Marketed in a Southwest Municipality of Bahia}

\begin{abstract}
Water, a substance indispensable to the health and maintenance of the human body, as well as all living organisms on our planet, also stands out as a means of disseminating pathogenic microorganisms, such as total coliforms and Escherichia coli, which are indicators of fecal contamination. Therefore, the present study was carried out with the purpose of verifying the quality of mineral water sold in Vitória da Conquista / B A trade, using Aquatest Coli® (Laborclin),, to carry out the analyzes according to the manufacturer's instructions. The results showed the absence of total coliforms and of Escherichia coli in all the analyzed samples, being therefore suitable for consumption. In studies carried out in other municipalities, high contamination rates were found for total coliforms and Escherichia coli, which justifies consumer insecurity.
\end{abstract}

Keywords: Mineral water. Microbiological analysis. Total coliforms. Escherichia coli.

\footnotetext{
${ }^{1}$ Graduanda em Farmácia pela Faculdade Independente do Nordeste - FAINOR. E-mail: giselenmattos@hotmail.com. Vitória da Conquista, Bahia, Brasil.

2 Graduanda em Farmácia pela Faculdade Independente do Nordeste - FAINOR. E-mail: lucianaglima2011@hotmail.com. Vitória da Conquista, Bahia, Brasil.

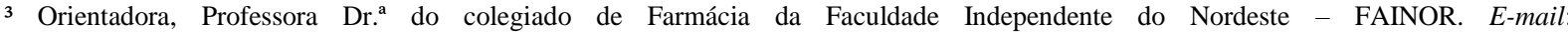
viviane@nutrisegura.com.br. Vitória da Conquista, Bahia, Brasil.

4 Doutor em fisiologia humana.E-mail: steniofernando@gmail.com.
} 


\section{Introdução}

Desde tempos imemoriais, a água, substância polar composta por um átomo de oxigênio e dois de hidrogênio, tem sido reconhecida como uma substância vital presente na natureza, ela é indispensável para a conservação dos ecossistemas e manutenção de toda a biologia do planeta Terra. Inclusive o ser humano, já que proporciona a distribuição dos nutrientes pelos órgãos e ajuda a regular a temperatura do corpo, dentre outros usos (CASTRO et al, 2012) (OLIVO; ISHIKI, 2014).

Aproximadamente $60 \%$ do peso corpóreo de um indivíduo adulto e saudável consiste em água, que se divide em dois compartimentos principais, que são o líquido extracelular e o líquido intracelular. Ela é indispensável para que ocorram os processos fisiológicos de digestão, absorção e excreção, é essencial na estrutura e função do sistema circulatório, além de ser um meio de transporte para nutrientes e substâncias corpóreas. Consumindo água em quantidade insuficiente, os rins compensam conservando água e excretando uma urina mais concentrada, sendo assim, é importante beber água em abundância (SERAFIM et al, 2004).

De acordo com o texto intitulado como o código de águas minerais, disposto no decreto de lei $N^{\circ} 7.841$, de 8 de agosto de 1945, a água mineral é aquela oriunda tanto de fontes naturais quanto de fontes artificialmente captadas, onde a sua composição química ou propriedades físicas ou físico-químicas se difere das águas comuns, possuindo propriedades que lhes atribua uma ação medicamentosa (ABINAM).

A água mineral natural é retirada diretamente de fontes naturais ou através da extração de águas subterrâneas. Ela é caracterizada pelo seu conteúdo definido e constante de certos sais minerais, oligoelementos e outros constituintes. A água mineral natural não deve desenvolver e ou agregar substâncias físicas, químicas ou biológicas que possam atribuir risco à saúde do consumidor e ou alterar a composição original, obedecendo-se a legislação vigente de Boas Práticas de Fabricação (BRASIL, 2005).

Distúrbios gastrointestinais têm ocorrido após o consumo de água mineral natural, mesmo com a visão geral de que estes produtos são seguros e de que o consumo deste tipo de água proporciona um estilo de vida saudável. Essas ocorrências estimularam o estudo de sua microbiologia. No ano de 1974, na Europa, mais precisamente no comércio de Portugal, água mineral não carbonatada e engarrafada foi considerada como sendo o meio de transmissão de cólera (SANT'ANA, 2003). 
A exploração de água mineral no Brasil é regulamentada pelo Departamento Nacional da Produção Mineral e controlada pelo Ministério de Minas e Energia. Já o dever de zelar pelo controle da qualidade cabe ao Ministério da Saúde. Em sua análise microbiológica, a água mineral deve incluir contagem de coliformes totais, enterococos, Pseudomonas aeruginosa, clostrídios sulfito redutores ou Clostridium perfringens e coliformes termotolerantes ou Escherichia coli (GOMES et al, 2015).

O consumo crescente de água mineral no Brasil é o reflexo de uma provável falta de confiança na qualidade microbiologia da água ofertada, particularmente nas grandes cidades. Sendo um bem apreciável e indispensável à vida, deve-se zelar por uma contínua averiguação microbiológica da água mineral à venda no comércio, assegurando assim a qualidade do produto ofertado. Os coliformes termotolerantes são indicadores de contaminação fecal, sendo aplicados como critério para determinação da condição das águas em geral (RESENDE ; PRADO, 2008).

Visando a verificação microbiológica da água mineral, o presente artigo teve como finalidade efetuar a análise microbiológica de água mineral lacrada e engarrafada em garrafas plásticas de $500 \mathrm{~mL}$, disponível no comércio do município baiano, buscando reconhecer uma eventual existência de coliformes fecais nas amostras obtidas.

\section{Materiais e Métodos}

\section{Caracterização do local da apuração e delimitação das amostras}

A pesquisa microbiológica em água mineral engarrafada foi realizada no município situado na região sudoeste do estado da Bahia. No comércio, em horário comercial, foram coletadas 24 amostras, sendo 2 amostras por lote, 2 lotes por marca, de 6 marcas diferentes de água mineral engarrafadas e lacradas em garrafas plásticas de $500 \mathrm{~mL}$, foram transportadas para o laboratório para ser realizada a análise microbiológica através do kit Aquatest Coli. 


\section{Técnicas para avaliação da água mineral}

A técnica foi desenvolvida de acordo com a bula do fabricante, o Aquatest Coli foi adicionado na amostra, sendo incubada por $24 \mathrm{~h}$ a $35( \pm 0,5){ }^{\circ} \mathrm{C}$. A alteração de tonalidade para o amarelo é designação do grupo coliforme, e a emissão de fluorescência representa a Escherichia coli. A sensibilidade da metodologia é à partir de $1 \mathrm{UFC} / \mathrm{mL}$ de amostra (LABORCLIN).

Lavou-se os recipientes de vidro de $100 \mathrm{~mL}$ e suas respectivas tampas com água corrente e sabão neutro, posteriormente foram lavados com água destilada e foram autoclavados para que pudessem ser preenchidos com as amostras. Foram retirados os rótulos das garrafas plásticas, e com um marcador, foram identificadas por letras de $\mathrm{A}$ a $\mathrm{F}$ de acordo com a respectiva marca, e de acordo com os lotes identificadas como L1 ou L2.

Cada recipiente de vidro que foi autoclavado recebeu $100 \mathrm{~mL}$ de sua amostra correspondente e também foram identificados de acordo com as mesmas. As amostras foram postas ao lado do bico de Bunsen, onde realizou-se o procedimento. Posteriormente as amostras foram levadas para a estufa, de onde foram retiradas para leitura após 24 horas.

\section{Resultados e Discussão}

Conforme os resultados adquiridos, das 24 amostras de água mineral engarrafada comercializada no município baiano, nenhuma revelou a presença de coliformes totais e/ou Escherichia coli, estando portanto todas aprovadas para este parâmetro de acordo a legislação vigente (quadro 1).

\begin{tabular}{|c|c|c|c|c|c|c|c|c|}
\hline$\underline{\text { Lote }}$ & Amostra & Parâmetro & $\frac{\text { Marca }}{\underline{\mathbf{A}}}$ & $\frac{\text { Marca }}{\underline{\mathbf{B}}}$ & $\frac{\text { Marca }}{\underline{\mathrm{C}}}$ & $\frac{\text { Marca }}{\underline{\mathbf{D}}}$ & $\frac{\text { Marca }}{\underline{\mathbf{E}}}$ & $\frac{\text { Marca }}{\underline{F}}$ \\
\hline \multirow{4}{*}{1} & \multirow[t]{2}{*}{$\mathbf{A}$} & $\begin{array}{c}\text { Coliformes } \\
\text { totais }\end{array}$ & Ausência & Ausência & Ausência & Ausência & Ausência & Ausência \\
\hline & & E. Coli & Ausência & Ausência & Ausência & Ausência & Ausência & Ausência \\
\hline & \multirow[t]{2}{*}{ B } & $\begin{array}{c}\text { Coliformes } \\
\text { totais }\end{array}$ & Ausência & Ausência & Ausência & Ausência & Ausência & Ausência \\
\hline & & E. Coli & Ausência & Ausência & Ausência & Ausência & Ausência & Ausência \\
\hline
\end{tabular}




\begin{tabular}{|c|c|c|l|l|l|l|l|l|}
\hline \multirow{2}{*}{2} & \multirow{2}{*}{ A } & $\begin{array}{c}\text { Coliformes } \\
\text { totais }\end{array}$ & Ausência & Ausência & Ausência & Ausência & Ausência & Ausência \\
\cline { 3 - 8 } & & $\boldsymbol{E}$ C Coli & Ausência & Ausência & Ausência & Ausência & Ausência & Ausência \\
\cline { 2 - 8 } & \multirow{2}{*}{ B } & $\begin{array}{r}\text { Coliformes } \\
\text { totais }\end{array}$ & Ausência & Ausência & Ausência & Ausência & Ausência & Ausência \\
\cline { 3 - 8 } & & $\boldsymbol{E}$ Coli & Ausência & Ausência & Ausência & Ausência & Ausência & Ausência \\
\hline
\end{tabular}

Quadro 1: Avaliação microbiológica das amostras de água mineral envasadas e lacradas em embalagens plásticas individuais de $500 \mathrm{~mL}$, disponíveis no comércio do município baiano

Já em um estudo desenvolvido por Yousaf e Chaudhry (2013), no microbiology laboratory of the Combined Military Hospital $(\mathrm{CMH})$, em Lahora, a segunda maior cidade do Paquistão, com uma população estimada em mais de 10 milhões. Das 24 amostras de marcas de diferentes águas minerais disponíveis no mercado, duas das marcas analizadas os testes deram positivo para contaminação por bactérias e, sendo assim, foram designadas como sendo impróprias para o consumo humano pelo laboratório de microbiologia do $\mathrm{CMH}$ de Lahore.

Em Lahore, as duas marcas que foram declaradas impróprias para consumo humano estavam altamente contaminadas, com contagem total de coliformes de 180+/100 mL de amostra de água submetida a teste. As 22 marcas restantes não apresentaram contaminação bacteriana e foram consideradas aptas para o consumo humano.

Em outro estudo realizado por Svagzdiene (2010) em Wellington, capital da Nova Zelândia. Foram coletadas amostras de 38 marcas diferentes de água engarrafada importada e também local, todas as amostras coletadas deram negativo para Escherichia coli, porém, três das 38 amostras continham coliformes totais. Todas as marcas que deram positivo para coliformes foram marcas locais vendidas em Wellington, as demais marcas, importadas, não apresentaram contaminação.

Voltando ao Brasil, em uma análise microbiológica desenvolvida por Cunha e seus colaboradores (2012) na cidade de Macapá no estado do Amapá, onde as amostras de água mineral foram adquiridas no comércio local, também foi encontrado sinal de contaminação por Escherichia coli em uma de suas amostras.

No que diz respeito aos aspectos microbiológicos, ainda que não haja indícios bacteriológicos nas amostras obtidas de água mineral (coliformes totais e E. coli), na literatura outros parâmetros são levados em conta além dos comumente utilizados a fim de realizar a análise microbiana. A ausência de coliformes ou E. coli não exclui, uma possível presença de 
fungos e filamentosos, mesmo que a análise bacteriológica tenha um resultado negativo. Desconsiderá-los traz riscos à saúde, principalmente para os consumidores não saudáveis como pacientes imunocomprometidos, que são mais suscetíveis à infecção (PONTARA, 2011).

Quanto à legislação para águas minerais, sofreu uma atualização pela Resolução RDC n. 54, de 15 de junho de 2000, o que melhorou o espectro microbiológico a ser avaliado, contudo, continuou insatisfatório na regularização e controle de qualidade, em discordância com o padrão designado pela legislação internacional para o comércio. Com isso, o risco de contaminação dos consumidores deste produto permaneceu, anos mais tarde, as Resoluções RDC n' 274 e 275 , de 22 de setembro de 2005 foram criadas, levando em conta a necessidade de modernização da legislação sanitária de alimentos, fundamentada no enfoque da verificação de risco e da prevenção de prejuízos à saúde dos consumidores (ALVES et al, 2002).

\section{Conclusão}

Podemos afirmar que as águas analisadas não apresentaram contaminação por coliformes totais e $E$. coli o que atende a legislação em vigor para esses parâmetros. Já em estudos similares realizados em outros municípios, constatou-se a presença de coliformes e $E$. coli. Em alguns destes municípios as amostras estavam altamente contaminadas. Isso demonstra a importância de estudos similares, assim como o monitoramento e a fiscalização das águas minerais engarrafadas presentes no comércio.

\section{Referências}

ABINAM - Associação Brasileira da Indústria de Águas Minerais. Código de Águas Minerais. Decreto-Lei $\mathrm{N}^{\circ}$ 7.841, de 8 de agosto de 1945. São Paulo - SP. Disponível em: http://www.abinam.com.br/materias.php?cd_secao=34\&codant=\&friurl=:-Codigo-de-AguasMinerais-.

ALVES, $\mathrm{N}$ et al. Análise microbiológica de águas minerais e de água potável de abastecimento. Marília - SP. Revista de Saúde Pública, v. 36, n. 6, 2002.

BRASIL. Resolução RDC n 274, de 22 de setembro de 2005. Aprova o "Regulamento técnico para águas envasadas e gelo". ANVISA - Agência Nacional de Vigilância Sanitária. 
BRASIL. Resolução RDC n 275, de 22 de setembro de 2005. Aprova o "Regulamento técnico de características microbiológicas para água mineral natural e água natural". ANVISA Agência Nacional de Vigilância Sanitária.

CASTRO, L et al. Avaliação Microbiológica de Diferentes Marcas de Água Mineral. Revista Baiana de Saúde Pública. v. 34, n. 4, 2010.

GOMES, T et al. Avaliação Microbiológica de Água Mineral Comercializada no Município de Itabuna - Bahia. Eletronic Journal of Pharmacy. vol. 12, n. 4, 2015. Disponível em: https://revistas.ufg.br/REF/article/view/36762/pdf.

LABORCLIN - produtos para laboratórios ltda. Aquateste Coli. Disponível em: http://www.interlabdist.com.br/dados/produtos/bula/doc/1016748ca7bcb1dc7c.pdf.

OLIVO, A; ISHIKI, H. Brasil frente à escassez de água. Presidente Prudente - SP, 2014. Disponível em: http://revistas.unoeste.br/revistas/ojs/index.php/ch/article/viewFile/1206/1279.

PONTARA, A et al. Microbiological monitoring of mineral water commercialized in Brazil. Brazilian Journal of Microbiology, v. 42, n. 2, 2011.

RESENDE, A; PRADO, C. Perfil Microbiológico da Água Mineral Comercializada no Distrito Federal. SaBios: Revista de Saúde e Biologia. v. 3, n.2, 2008.

SANT'ANA, A et al. Qualidade Microbiológica de Águas Minerais. Campinas, 2003. Disponível em: http://www.scielo.br/pdf/cta/v23s0/19495.

SERAFIM, A et al. Importância da água no organismo humano. Vidya Revista Eletrônica. v. 24, n. 41. Centro Universitário Franciscano, 2004.

SVAGZDIENE, R. A Study of the Microbiological Quality of Bottled Water Sold in New Zealand. Massey University, Wellington, Nova Zelandia, 2010. Disponível em: https://mro.massey.ac.nz/bitstream/handle/10179/2291/02_whole.pdf.

YOUSAF, S; CHAUDHRY, M. Microbiological Quality of Bottled Water Available in Lahore City. Journal of Pioneering Medical Sciences. V. 3, n. 2, 2013.

Como citar este artigo (Formato ABNT):

MATTOS, Gisele Norberto; LIMA, Luciana Gonçalves; VIEIRA, Viviane Figueiredo; DUARTE, Stênio Fernando Pimentel. Avaliação de Coliformes Totais e Escherichia Coli em Diferentes Lotes de Água Mineral Comercializadas em um Município do Sudoeste Baiano. Id on Line Revista Multidisciplinar e de Psicologia, 2017, vol.11, n.38, p.566-572. ISSN: 1981-1179.

Recebido: 01.10.2017

Aceito: 03.11.2017 